\title{
The Higher Education of Ukraine in the Global Educational Space
}

\author{
1, "Svitlana Soroka (D; ${ }^{2}$ Tetiana Akimova \\ ${ }^{1,2}$ Petro Mohyla Black Sea National University, Mykolayiv, Ukraine \\ *Corresponding author: svet230879@gmail.com
}

\begin{abstract}
The article presents the analysis of the Ukrainian state policy in the field of higher education in terms of its integration into the global educational space. The process of management and financing of Ukrainian higher education institutions, the quality and quantity of teaching staff, the ratio of the number of teaching staff, and students are considered. The authors determine the reasons for the slow integration of Ukrainian higher education into the global educational space, low ratings of Ukrainian higher education institutions in the world ranking of universities. The main problems of Ukrainian higher education institutions are inadequate financing from the state budget, restriction of their autonomous right to set the rules, the decrease in the number of students, and the growing quantity of lecturers which exceeds the number of students in higher education institutions. The authors made recommendations for improving the quality and competitiveness of Ukrainian higher education in the world. Among them, in particular, are developing criteria for forming a rating of higher education institutions in Ukraine that will coincide with the world and European requirements, increasing academic exchanges with the world's leading universities, forming an effective model of state policy for the development of higher education in Ukraine focused on improving the institutional and organizational structure.
\end{abstract}

Keywords: higher education, global educational space, teaching staff, higher education institutions.

\section{Introduction}

Modern education technologies are developing rapidly, and education is becoming one of the main criteria for the development of global society. It is the higher education system that is the main generator of knowledge implemented in the course of the research, teaching, and methodological activities of higher education institutions. In order to be effective and competitive, Ukrainian higher education must be developed in the context of global educational space. Our desire to achieve 
international and European educational standards requires reforming the system of higher education, which is the most crucial element of its modernization.

The purpose of the article is to analyze the development of the higher education system of Ukraine and its place in the global educational space, development of recommendations for improving the quality and competitiveness of Ukrainian higher education in the world.

International cooperation with the European Union and bilateral cooperation with its member states form the grounds for international cooperation of Ukraine in the research sector. Since the proclamation of independence in 1991, Ukraine has been regularly attempting to open its national research system for the international research community. Today, one of the main priorities of Ukrainian international cooperation in research is to integrate into the European Research Area (Final Report, 2017).

\section{Literature Review}

Some aspects of the development of higher education in Ukraine and its place in the global educational space have become a topical issue of recent research. The impetus for interest was the reform of the higher education system. However, it did not result in improving the quality of student training and teaching staff of higher education institutions, although it contributed to the introduction of world standards into Ukrainian higher education and its integration into the global educational space. Many research papers are dealing with the identification of problems in modern higher education and areas for their improvement under international standards.

Voloshinov, Osadchyi \& Osadcha (2018) analyzed the current global trends in education in order to identify the main trends of higher education in Ukraine. In particular, they paid attention to the impact of information and communication technology on further improvement of material and technical, and educational, and methodological provision of higher education institution and transformation of approaches for teaching and learning; the quality of education which prompts to the search for certification mechanisms and the integration of national quality assurance schemes at the international level; the era of the information society and increasing the role of relevant data which lead to a constant analysis of the work of the law enforcement in conditions of uncertainty and rapid change in order to make managerial and strategic decisions. 
The authors of the "National Report on the State and Prospects of Education Development in Ukraine" consider that "the main strategic areas of higher education modernization include: reorganization of the higher education institutions network; bringing the students contingent in line with the real higher education resource base; reform of the public funding of higher education institutions; the establishment of the national ranking system for higher education institutions; consolidation of existing higher education institutions in regions through their association in the powerful national, regional universities" (Kremen, 2017).

Dluhopolskyi (2017) believes that to increase students' motivation for learning, and academic staff's for teaching and academic activities, in individual universities it is reasonable: to lower the level of red tape in the learning process while dedicating more time for research work, which requires both an active position of the Ministry of Education and Science of Ukraine, as well as of the heads of individual universities; to help professors in higher education institutions to learn foreign languages, stimulate them to conduct lectures and seminars both in Ukrainian and English with the help of bonuses, grants and other types of rewards; to increase salaries (by applying a system of rewards and bonuses) for best professors and researchers, who create a positive image of the university (reputation capital); to evaluate the level of professional skills of the professors when signing job contracts on the basis of explicit criteria (namely, quality of publications instead of their quantity, the level of foreign language proficiency, engagement in international programs, Hirsch index, scientific and expert activities, learning and teaching activities, academic degree and academic rank).

Sikorskaya (2017), in her article, claims that Ukrainian higher education institutions face several challenges in their attempts to internationalize. Their efforts are restricted by a lack of funding and a lack of strategic vision from the government. Some national reforms have triggered the internationalization of Ukrainian higher education institutions, but the responsibility for implementation and quality assurance rests with the institutions. In order to adapt to changing local and global needs and strengthen the quality of research and teaching, Ukrainian universities must make a robust effort to promote internationalization.

Characterizing reforms in the field of higher education of Ukraine and the problems of its internationalization Knutson \& Kushnarenko (2015) noted that "universities tend towards hierarchical and bureaucratic self-organization and are notoriously resistant to change. The Ukrainian higher education system is perhaps starting at an earlier place than other countries where universities are freer to choose program content, make financial decisions, create degree-granting and credit transfer policies, and hire faculty via open and transparent competition. In Ukraine, such innovations 
could be jeopardized if opposition causes delays to change, creating uncertainty, and lowering morale".

The analysis of the available literature indicated the need for in-depth study of such aspects as analysis of the place of Ukrainian higher education in world rankings, the competitiveness of higher education both within the country and in the world, the impact of higher education funding on its quality in the context of integration into the global educational space. The authors decided to research these aspects of this study.

\section{Methodology}

Let us define the key concepts that were used in the article. The authors use the concept "higher education" as it is defined in the Law of Ukraine "On Higher Education," adopted in 2014. Higher education is a set of systematized knowledge, skills, and practical skills, ways of thinking, professional, ideological and civic qualities, moral and ethical values, other competencies acquired in a higher education institution (scientific institution) in the relevant field of knowledge at higher levels of education, which are more complicated than the level of complete general secondary education.

The term "global educational space" has different interpretations among scholars. Let us look at the main ones. Lukovtseva (2008) claims that "the global educational space unites national educational systems of different types and levels, which differ significantly in philosophical and cultural traditions, the level of goals and objectives, and their qualitative state. Therefore, we should talk about the modern global educational space as a developing unified organism with emerging global trends and preserving diversity in each educational system".

Baranovska (2018) believes that the formation of the modern global educational space is a union of national educational systems of different types and levels, which differ in their educational and cultural traditions, goals, objectives, and quality.

The global educational space is the result of the constructive activity of educational entities at the international level, a place where "the main goals of national and world educational policy are set and implemented, through the whole set of educational institutions and their governing bodies" (Liferov, 1997). Due to this, differences and competition between the educational and cultural systems of the world are overcome, their dialogue is established based on the development of inter-world and intercultural communications. Within the framework of the world educational space, 
there is cooperation and mutual work of states in research, management, educational, cultural activities, implementation of joint educational projects; there is free access to information about the condition and activity of education system, the coordination of the state educational standards.

Based on the basic definitions of the concept "global educational space," it should be noted that the reform of the higher education in Ukraine is characterized by the search for the best cooperation between the established pedagogical traditions, public administration in the field of education and new trends brought by entering the global educational space.

To achieve the objectives of the study, we used several research methods: accumulation and fixation of new factual data on the issue, theoretical, analytical and synthetic processing of the obtained data, their comparison, grouping, disclosing relationships, generalization, the formation of scientific conclusions. All these actions were carried out based on the materialist dialectics principle, which is to consider objects in interrelation and interdependence, inductive generalization, and deductive conclusion.

The study used the method of Data analysis, in particular, to determine the place of Universities in Ukraine in the QS World University Rankings, Number of HE institutions, Number of students and teachers, Financing of higher education in Ukraine. The data analysis technique was focused on statistical modeling and knowledge discovery for predictive rather than purely descriptive purposes.

The authors used the method of Scientific modeling to determine the correspondence of the number of teachers to the number of students in Ukrainian higher education institutions of the III-IV accreditation levels. We developed a statistical model that embodied a set of statistical assumptions concerning the generation of sample data, namely the average ratio of students to teachers, the number of students in bachelor's and master's programs, compliance with licensing conditions regarding the number of teachers and the ratio of students and teachers.

A comparative analysis method was used to compare the leading indicators of higher education in Ukraine and other countries. This allowed us to determine the role and place of Ukrainian higher education in the global educational space. This method was also used to compare the state of higher education in Ukraine in the dynamics over the years.

\section{Results and Discussions}


In order to understand the place of Ukrainian higher education in the global educational space, let us consider QS World University Rankings 2018. The rating is based on six indicators that reflect the scientific and academic achievements of professors, students, and university graduates. They are the following: Academic Reputation, Employer Reputation, Faculty / Student Ratio, Citations per Faculty, International Faculty Ratio, and International Student Ratio. Table 1 presents the top ten universities of the QS World University Rankings 2018 and Ukrainian higher education institutions in it (QS World University Rankings, 2018).

\section{Table 1}

Universities of the World by QS World University Rankings 2018

\begin{tabular}{|c|c|c|c|c|}
\hline $\begin{array}{c}\# \\
\text { RANK }\end{array}$ & UNIVERSITY & $\begin{array}{c}\text { International } \\
\text { staff, } \%\end{array}$ & $\begin{array}{c}\text { International } \\
\text { students, \% }\end{array}$ & $\begin{array}{l}\text { Students } \\
\text { per staff } \\
\text { member }\end{array}$ \\
\hline 1 & $\begin{array}{l}\text { Massachusetts Institute of } \\
\text { Technology (MIT), USA }\end{array}$ & $56 \%$ & $34 \%$ & 4 \\
\hline 2 & Stanford University, USA & $48 \%$ & $23 \%$ & 4 \\
\hline 3 & Harvard University, USA & $30 \%$ & $24 \%$ & 5 \\
\hline 4 & $\begin{array}{c}\text { California Institute of } \\
\text { Technology, USA }\end{array}$ & $37 \%$ & $29 \%$ & 2 \\
\hline 5 & $\begin{array}{c}\text { University of Cambridge, } \\
\text { United Kingdom }\end{array}$ & $42 \%$ & $36 \%$ & 3 \\
\hline 6 & $\begin{array}{l}\text { University of Oxford, United } \\
\text { Kingdom }\end{array}$ & $44 \%$ & $37 \%$ & 3 \\
\hline 7 & $\begin{array}{c}\text { University College London, } \\
\text { United Kingdom }\end{array}$ & $40 \%$ & $48 \%$ & 5 \\
\hline 8 & $\begin{array}{c}\text { Imperial College London, } \\
\text { United Kingdom }\end{array}$ & $53 \%$ & $54 \%$ & 4 \\
\hline 9 & University of Chicago, USA & $26 \%$ & $25 \%$ & 6 \\
\hline 10 & $\begin{array}{c}\text { ETH Zurich - Swiss Federal } \\
\text { Institute of Technology, } \\
\text { Switzerland }\end{array}$ & $76 \%$ & $38 \%$ & 8 \\
\hline
\end{tabular}




\begin{tabular}{|c|c|c|c|c|}
\hline $401-410$ & $\begin{array}{l}\text { V. N. Karazin Kharkiv } \\
\text { National University, Ukraine }\end{array}$ & $0,3 \%$ & $27 \%$ & 8 \\
\hline $411-420$ & $\begin{array}{l}\text { Taras Shevchenko National } \\
\text { University of Kyiv, Ukraine }\end{array}$ & $0,6 \%$ & $3,2 \%$ & 8 \\
\hline $501-550$ & $\begin{array}{c}\text { National Technical } \\
\text { University of Ukraine "Igor } \\
\text { Sikorsky Kyiv Polytechnic } \\
\text { Institute", Ukraine }\end{array}$ & $0,2 \%$ & $1,5 \%$ & 8 \\
\hline $701-750$ & $\begin{array}{c}\text { National Technical } \\
\text { University "Kharkiv } \\
\text { Polytechnic Institute", } \\
\text { Ukraine }\end{array}$ & $0,3 \%$ & $6,7 \%$ & 9 \\
\hline $\begin{array}{l}801- \\
1000\end{array}$ & $\begin{array}{c}\text { Vasyl Stus Donetsk National } \\
\text { University, Ukraine }\end{array}$ & $0,5 \%$ & $1,6 \%$ & 10 \\
\hline $\begin{array}{l}801- \\
1000\end{array}$ & $\begin{array}{c}\text { Sumy State University, } \\
\text { Ukraine }\end{array}$ & $0,2 \%$ & $13 \%$ & 10 \\
\hline
\end{tabular}

Source: QS World University Rankings 2018.

The Ukrainian higher education institutions are listed after 400. The following factors can explain such low positions. First, there are few foreign teachers and students in Ukrainian higher education institutions (0.2-0.6\%) compared to the best universities in the United States and Great Britain (26-76\%). Only V. N. Karazin Kharkiv National University in Ukraine has the same number of international students as university ranking leaders; in others, it is quite low $1.5-13 \%$.

Second, in Ukrainian higher education institutions, the number of students per lecturer is $8-10$ to 1 . In the ranking of the best universities, this indicator is 3-5 students per 1 lecturer. Third, Ukrainian scholars publish very few studies in journals indexed in international scientific and metric databases. That happens because of poor foreign language qualification, which leads to the slow integration of domestic science into the world research area.

It should be noted that since 2009 there has been an increase in collective works of Ukrainian scholars and authors from the European Union countries in the databases of Web of Science Core Collection and Scopus. This is consistent with the global trend. In 2013 the total number of publications in the world almost doubled in comparison with 2003, but Ukrainian internationalization in this sphere remained 
below the average. Scientific specialization in the sphere of joint publications reflects the specialization of Ukraine. According to the Specialty Index, Ukraine is considered highly specialized in physics and astronomy, material science and chemistry, technology, mathematics, and sciences about the planet. Ukraine also has indicators similar to the global average in the areas of computer sciences, chemical engineering, and energy. All other areas have SI. index below 1, which indicates their "insufficient specialization" (Final Report, 2017).

It is interesting to consider the information on the contribution of different countries to the world research area. The rating is based on the analysis of the number of citations in scientific journals. Today, this indicator can be used as a general indicator of the development of science and the economy of the country. This rating was developed by the Institute of Scientific Information (Philadelphia, USA), and renamed the Healthcare \& Science business at Thomson Reuters. It annually publishes the Science Citation Index (Journal Citation Reports, 2018). Table 2 shows the contribution of countries to the world scientific process. As can be seen, 50\% belong to highly developed countries, namely the United States, Japan, and the United Kingdom. The contribution of Ukraine is less than $1 \%$.

Table 2

Contribution to the world scientific process of different countries according to the Institute of Scientific Information (Philadelphia, USA)

\begin{tabular}{|c|c|c|c|c|c|}
\hline Country & $\%$ & Country & $\%$ & Country & $\%$ \\
\hline USA & 30,817 & Spain & 2,028 & Finland & 0,793 \\
\hline Japan & 8,244 & Sweden & 1,841 & Austria & 0,652 \\
\hline United Kingdom & 7,924 & India & 1,643 & Brazil & 0,646 \\
\hline Germany & 7,184 & Switzerland & 1,640 & Ukraine & $\mathbf{0 , 5 7 8}$ \\
\hline France & 5,653 & China & 1,339 & Norway & 0,569 \\
\hline Canada & 4,302 & Israel & 1,074 & South Korea & 0,546 \\
\hline Russia & 4,092 & Belgium & 1,059 & New Zeland & 0,426 \\
\hline Italy & 3,394 & Dania & 0,962 & Republic of South Africa & 0,415 \\
\hline Netherlands & 2,283 & Poland & 0,913 & Greece & 0,411 \\
\hline
\end{tabular}




\begin{tabular}{|l|l|l|l|l|l|}
\hline Australia & 2,152 & Taiwan & 0,805 & Hungary & 0,398 \\
\hline
\end{tabular}

Source: Journal Citation Reports (2018).

In order to increase the number of publications of Ukrainian scientists in the Web of Science Core Collection and Scopus databases and their contribution to the world scientific process, the Ministry of Education and Science of Ukraine approved the Order "On the Procedure of Assigning Scientific Rankings to Scientific and Research Workers" (2016). Thus, to get the academic rank of a professor, a scientist must have, in addition to other criteria, at least two publications in periodicals included in the scientific databases Scopus or Web of Science, to get the academic rank of an associated professor the number of publications must be not less than one.

Thus, the issue of reforming higher education and joining the ERA is one of the priorities of the state policy of Ukraine by introducing radical changes aimed at improving the quality, accessibility, and competitiveness of education in new economic and socio-cultural conditions.

However, we should admit the fact that all attempts to reform the system of higher education in Ukraine and make it competitive in the world educational market have not produced real results yet. The adoption of the new law "On Higher Education" on July 1, 2014, has not radically changed the situation. Thus far, the state and the ruling regime has managed to preserve a near-monopoly on overall university guidance, exercising power through its educational authorities, and denying true university autonomy to those few institutions capable of implementing it successfully. Despite some progressive rhetoric, the state remains a major foe to the university autonomy (Osipian, 2017).

There is also a question of whether the management of higher education in Ukraine is consistent with the basic requirements of the Bologna process. In this context, it should be agreed with the opinion of the researchers that "hybridization of the Bologna process in Ukraine has demonstrated to us that Ukrainian education is at a critical point. Our situation is specific because without canceling the previous standards, we borrow new, mimicking the observation of both the first and the second. Many questions hang in the air unanswered, and new legislative initiatives not only do not untangle old issues but also create an additional element of chaos and uncertainty. It is not clear whether the Bologna process is still relevant after 11 years of implementation in Ukraine. Does Ukraine retain its interest in the Bologna process?" (Gomilko, Svyrydenko \& Terepyshchyi, 2016). 
We will try to consider the details of modern higher education, socio-economic priorities and directions of state policy in the field of higher education in Ukraine. Among the main problems hampering the development of higher education in Ukraine are a large number of higher education institutions, steady trends in reducing the number of students, and increasing the number of scientific and pedagogical workers. There are 289 higher education institutions (universities, academies/institutes) without taking into account the temporarily occupied territories of the Autonomous Republic of Crimea, the city of Sevastopol, Donetsk, and Luhansk regions in Ukraine. From the times of hyperinflation (1994-2005) to 2010, the number of higher education institutions of the III-IV accreditation levels (institutes, academies, universities, and conservatories) had grown rapidly ${ }^{1}$. After 2010 the situation became stable, and the number of higher education institutions during the last four years remained almost unchanged (Fig. 1).

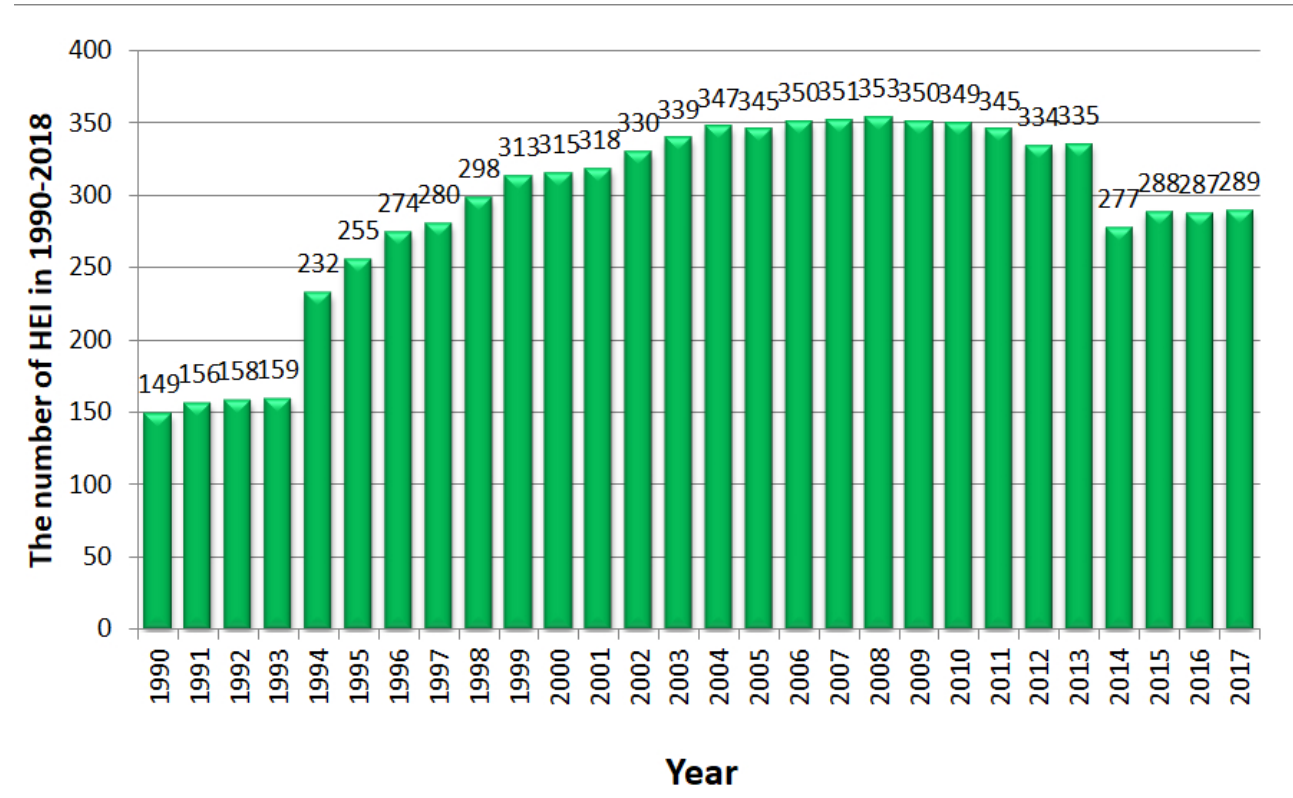

Figure 1. Number of higher education institutions in 1990-2018

Source: Higher education in Ukraine in 2017 (2018).

\footnotetext{
${ }^{1}$ The current Law of Ukraine "On Higher Education", adopted in 2014, abolished accreditation levels. Now all higher education institutions are divided into three groups: university, institute or academy, college.
} 
The last decade has a stable number of higher education institutions. In contrast to it, the number of students in these institutions has been reduced (Fig 2). Statistical data show that the number of students has been proliferating since 1993. Since 2007 this indicator has been gradually decreasing, which can lead to a minimum number of enrolled students in 2020 (Ponomarenko, 2011). According to the prognosis, the number of students enrolled in higher education institutions in 2020 will be equal to $50 \%$ of the number of students enrolled in 2007.

This is due to the demographic crisis that took place in 2001 and will significantly affect the number of students, not only in 2020. The number of students enrolled in higher education institutions will be rapidly decreasing from 2018 to 2024 and come down to 1.5 million students, which is twice less than in 2007.

It should be noted that the dynamics of the contingent of students does not take into account the number of Ukrainian youth who go to study abroad. Thus, according to the research of the SEDOS analytical center, the number of Ukrainians who went to study at foreign universities in the 2014/2015 school year was 66668 people. Poland, Germany, Russia, Canada, Italy, the Czech Republic, the USA, Spain, Austria, France, and Hungary continue to be among the most desirable countries for education. The dynamics of growth amounted to $176 \%$ from 2009 to 2016. Comparing 2015 and 2016, the growth was almost 20\% or 10934 people. Moreover, $2 / 3$ of this increase was made by the Ukrainians studying at Polish universities (Stadny, 2017).

\section{The number of students in HEI, ths}

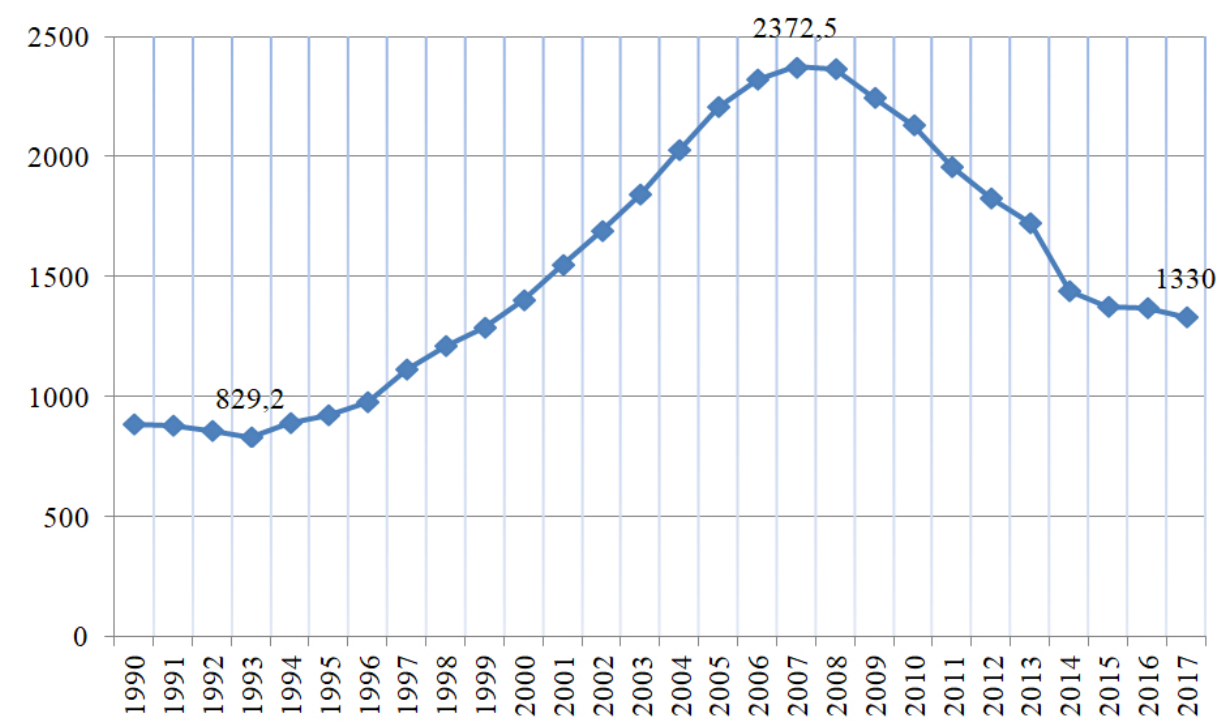


Figure 2. The number of students in Ukrainian higher education institutions in dynamics

Source: Higher education in Ukraine in 2017 (2018).

Such a decrease in the number of students will have a significant impact on other indicators of higher education in Ukraine, especially on:

- the number of teaching staff in higher education institutions;

- the teaching load;

- the number of higher education institutions;

- the size of the scholarship;

- payments to higher education institutions employees.

Another problem that has recently appeared is the inconsistency of the required and existing number of lecturers with academic degrees in higher education institutions. The analysis of statistical data (Fig. 3) shows that the number of students in higher education institutions of the III-IV accreditation levels during the years of independence has grown from 882.3 thousand in 1990/91 to 129.4 thousand people in 2017/2018. The smallest number of students was in 1993/1994 (829 000.2 people), and the largest was in 2007/2008 (2 372000.5 students). Thus, the number of students continuously increased 2.86 times from 1993 to 2007 (Higher education in Ukraine, 2018). An increase in the number of students has led to an increase in the number of higher education institutions from 149 to 353.

In turn, this caused a great need for scientific personnel, whose number has increased 2.1 times from 2003 to 2013. The government took action to create favorable conditions for fellowship in Ph.D. and postdoctoral programs. As a result, the number of postgraduate students increased from 13374 in 1990/91 to 34653 scholars in 2010/2011, and the number of postdoctoral fellows increased from 503 in 1991/92 to 1814 in 2012/2013. Since 2013, the number of postgraduate students and postdoctoral students has gradually increased. The data, on January 1, 2018, state that 24,786 postgraduate students and 1,646 postdoctoral students study in Ukraine (Higher education in Ukraine, 2018).

Figure 3 shows the total number of full-time students of higher education institutions, the total number of teaching staff with degrees of doctor and candidate of sciences, and the required number of teaching staff with degrees and titles to provide the process of education following the license conditions. The required number of 
scientists was calculated based on the average ratio of students to teachers. On the bachelor's program, it is ten students to one lecturer, and on the master's program, it is five to one. The proportion of full-time students on Bachelor programs to Masters is $55 \%$ to $45 \%$, respectively.

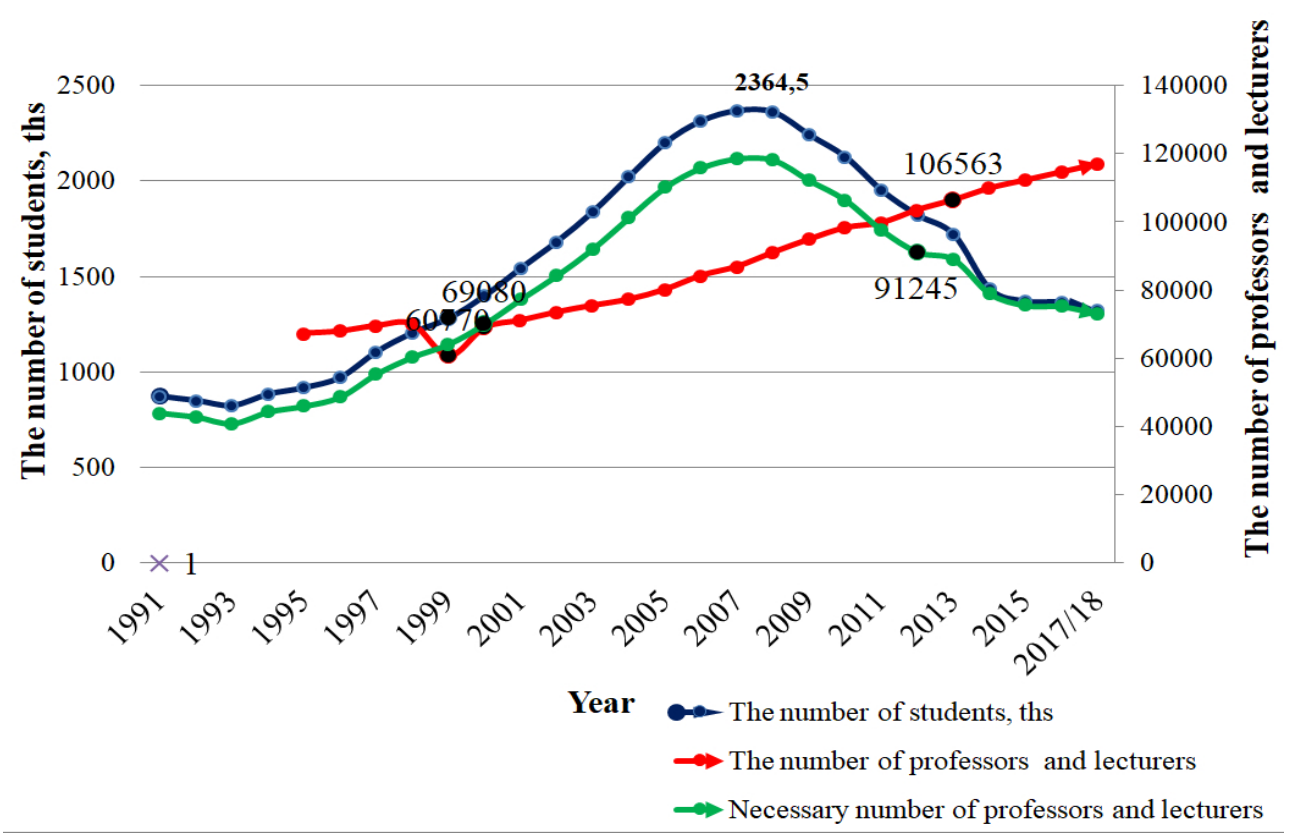

Figure 3. The correspondence of the number of teachers to the number of students in Ukrainian higher education institutions

Source: Compiled by the authors.

In the calculations, we met the license requirements for the number of lecturers with degrees and titles on the bachelor (40\%) and master's (95\%) programs. The above calculations do not claim to be precise, because they do not take into account the following factors: the number of associate professors without academic degrees, distance education, guidance for postgraduate students and doctoral students. At the same time, all of these factors are almost constant during the years under review, so they can be taken into account for a qualitative analysis of the situation with teaching staff provision.

Data analysis shows a radical change in the situation with the scientific and pedagogical staff:

- by 2010 the staffing needs exceeded the existing number of lecturers, and after 2010 there was a stable tendency of reducing the number of students and 
increasing the number of lecturers with degrees and titles that, in the end, has exceeded the needs of the educational sector;

- changes in teaching staff are much slower and more inertial than changes in the contingent of students;

- the trend for reducing the number of students will continue up to 2020, based on demographic forecasts, and during this time, the number of lecturers with degrees and titles will be increasing.

The government must take some steps to create new jobs in order to use the existing teaching staff effectively. We cannot rely on the employment of new candidates and doctors of sciences in scientific institutions, because the number of people in scientific institutions since 1990 has decreased from 313079 to 82032 people and has a steady tendency to decrease further (Higher education in Ukraine, 2018). On the background of these trends, there remains an essential problem of higher education in Ukraine, connected with insufficient funding of higher education institutions. The Ministry of Education and Science of Ukraine does not provide funds for the development of higher education institutions (Table 3).

\section{Table 3}

Financing of higher education in Ukraine

\begin{tabular}{|l|l|l|l|}
\hline Year & $\begin{array}{l}\text { Budget expenditures for higher } \\
\text { education, million UAH }\end{array}$ & $\begin{array}{l}\text { The proportion of } \\
\text { total budget } \\
\text { expenditures, } \%\end{array}$ & $\begin{array}{l}\text { The part of } \\
\text { GDP, \% }\end{array}$ \\
\hline 2010 & 24998,4 & 6,6 & 2,3 \\
\hline 2011 & 26619,6 & 6,4 & 2,0 \\
\hline 2012 & 29335,9 & 6,0 & 2,0 \\
\hline 2013 & 30003,1 & 5,9 & 2,1 \\
\hline $2014^{*}$ & 28340,5 & 5,4 & 1,8 \\
\hline $2015^{* *}$ & 30981,8 & 4,6 & 1,6 \\
\hline 2016 & 35233,6 & 4,2 & 1,5 \\
\hline 2017 & 38681,1 & 3,7 & - \\
\hline
\end{tabular}

*Until 2014, including the budgets of the Autonomous Republic of Crimea and the city of Sevastopol

**From 2015, without taking into account the expenditures of the Autonomous Republic of Crimea and Sevastopol

Source: Higher education in Ukraine in 2017 (2018). 
The analysis of higher education financing in Ukraine showed that the primary funding comes from the state budget (69.9\%), and the rest comes from physical persons $(30.1 \%)$, which is in line with European trends. However, we must take into account the level of inflation, the consumer price index, absolute and relative indicators of funding. The relative level of higher education institutions funding for 2014-2017 has decreased threefold. That has led to the fact that the state budget provides money for salary, payroll, stipends, and partly utilities.

Funds for the development of higher education institutions and capital expenditures are allocated in the amount of $0.3 \%$ of total funding. Although the funds for the development of higher education institutions have never been allocated in the required amount, some years ago, they were $3.5 \%$. They were spent on the material and technical re-equipment, repairing of premises, purchase of vehicles, appliances, and laboratory equipment. In 2000-2016, most developed countries in Europe, except for Italy, Ireland, and Portugal, systematically increased their higher education expenditures for capital needs. Leaders of higher education capital expenditures are Canada, Czech Republic, Sweden, Lithuania, and Latvia. Ukraine has reduced capital expenditure in higher education to zero (Bogolib, 2017).

In the conditions of insufficient state funding of higher education in Ukraine, higher education institutions should look for alternative sources of funding. The right solution for financial and staff problems of higher education in Ukraine would be to reduce the number of higher education institutions and consolidate them. On the one hand, Ukraine has 289 higher education institutions (universities, academies/institutes), which is too much. Combining several higher education institutions into one powerful regional education institutions will, first of all, create powerful education institutions with a developed material base, to simplify the management of the industry. On the other hand, the optimization will have some disadvantages. The consolidation of several departments of different higher education institutions into one ensures the availability of a vast teaching resource at once. This staff will be sufficient for the licensing and accreditation of any educational program. Thus, the need for further development of the department disappears, together with the incentives for writing thesis and monographs, textbooks, workbooks, etc. This will inevitably bring to scientific stagnation and degradation because of the elimination of competition.

According to UNESCO, some countries will deploy various socio-anthropological projects in the next 20 years. They will form new education systems to ensure the implementation of these projects. Taking into account the growing global competition, "educational areas" will be formed based on language and culture unity. Forming these education areas will be an acutely competitive process. According to 
UNESCO, the most potent educational areas will be the European-American English-speaking Education Area; the Chinese Education Area; Spanish-Latin America Education Area; Arab-Islamic Education Area. Each Education Area will have a leader country (or group of countries) exporting higher education. The processes of Education Areas formation will be superimposed by the processes of globalization of knowledge and the spread of education technologies of the new generation. Therefore, Ukraine needs to be included in the Education Area of European countries. These countries will have a significant increase in the young population, which will make the labor and education migration relevant to them.

\section{Findings and conclusions}

The active development of higher education in Ukraine and its integration into the global educational space requires the following steps. It is necessary to develop criteria for forming a rating of higher education institutions in Ukraine that will coincide with the world and European requirements. Ratings should be aimed at providing information on an objective assessment of the academic achievements of higher education institutions, the effectiveness of the higher education system in some regions, the demand for graduates, and the quality of training.

Taking into account the significant difference between the financial provision, scientific achievements of higher education and science of Ukraine and the world leaders in the field of education, it is evident that Ukrainian higher education institutions have to pass a long and challenging way to achieve the leading positions in world rankings.

It is necessary to increase academic exchanges with the world's leading universities (not less than $20 \%$ of both faculty and students). Low motivation to integrate education and science has led to the vacuum isolation of teachers and scientists from the realities of management, deprived of the opportunity to reproduce their scientific potential. Combined with low wages, this has shaped the attitude towards scientific work as an optional and formal part of work. The consequence of this situation was the formalization of scientific guidance for graduate and doctoral students, staff who are rarely involved in research, and have low activity of publications. All this together led to a further decline in the positions of Ukrainian higher education institutions in international rankings.

It is necessary to form a useful model of state policy for the development of higher education in Ukraine focused on improving the institutional and organizational structure and providing: 
- creation of new institutional mechanisms for regulating and stimulating the development of the higher education system;

- improving the state system of evaluation of educational institutions and ensuring the objectivity, reliability, and transparency of evaluation procedures;

- updating the structure and content of education;

- improvement of the system of state certification of scientific and scientificpedagogical staff;

- introduction of mechanisms of interaction between higher education institutions and employers, which will bring additional material, intellectual and other resources to the sphere of education;

- introduction of multi-channel financing models (state - enterprises households);

- formation of the system of life-long education.

Higher education institutions should develop as active market players with the assimilation of new practices: obtaining loans, signing agreements with enterprises and businesses. It is advisable to begin the active implementation of organizational, research, and investment activities leading to the commercialization of research. The effectiveness of this area of activity depends on the level of innovation potential of the higher education institution, institutional conditions, regulatory framework, and the availability of investment resources. The combination of these components is possible through joint ventures and the creation of small innovative enterprises in higher education institutions. This process will significantly attract the teaching staff, gifted youth, material and technical resources of the participants, and the managerial experience of enterprises. As a result, there will be formed stable industrial networks that will help higher education institutions to realize their intellectual potential.

\section{References}

Baranovska, N. (2018) Legacy of the World Educational Space and Its Influence on the Interaction of Education and Culture. Historical and Cultural Studies. 5 (1), 7-14. Available from: doi.10.23939.2018.05.007

Bogolib, T. (2017) Financing of higher education in Ukraine: problems and prospects for their solution. American Scientific Journal. 1 (9), 70-78. 
Derkach, L. M. (2017) Ukraine's integration into global and European educational space: problems, challenges and perspectives. International Scientific Bulletin. 3 (16), 39 49.

Dluhopolskyi, O. (2017) 'Internal quality assurance system in Ukrainian higher education: adopting the European Standards and Guidelines Higher education in Ukraine.' In Nikolaiev, Y. (ed.) Agenda for Reforms. Kyiv, Konrad -Adenauer -Stiftung Ukraine Office, pp. 29-35.

Final Report of the Independent European Audit of the National System of Research and Innovation of Ukraine (2017). Brussels, The European Commission. Available from: http://h2020.com.ua/wp-content/uploads/2017/03/KI-AX-16-008-UK-NTransl.pdf [Accessed June 1 2019].

Gomilko, O. Svyrydenko, D. \& Terepyshchyi, S. (2016) Hybridity in the higher education of Ukraine: global logic or local idiosyncrasy? Philosophy and Cosmology-Filosofiya $i$ Kosmologiya. 17, 177-199.

Higher education in Ukraine in 2017 (2018). Statistical Collection. Kyiv, State Statistics Service of Ukraine. Available from: http://www.ukrstat.gov.ua/druk/publicat/kat_u/publosvita_u.htm [Accessed June 1, 2019].

Journal Citation Reports (2018). Available from: https://clarivate.com/products/journalcitation-reports/ [Accessed June 1, 2019].

Knutson, S., \& Kushnarenko, V. (2015) Ukraine: The New Reforms and Internationalization. International Higher Education. (79), 18-19. Available from: doi.10.6017.2015.79.5850

Kremen, V. G., Lugovyy, V. I. \& Gurzhii, A. M. (2017) National Report on the State and Prospects of Education Development in Ukraine. Kyiv, National Academy of Educational Sciences of Ukraine.

Liferov, A. P. (1997) The main tendencies of integration processes in world education. Moscow, Moscow State Pedagogical University.

Lukovtseva, A. K. (2008) Psychology and pedagogy. Course of lectures. Moscow, University Book House.

"On Higher Education" Law of Ukraine (2014). Bulletin of the Verkhovna Rada, 2014, 37 38, 2004. Available from: http://zakon.rada.gov.ua/laws/show/1556-18 [Accessed June 1, 2019].

"On the Procedure of Assigning Scientific Rankings to Scientific and Research Workers" (2016). Order of the Ministry of Education and Science of Ukraine No. 13, dated January 14, 2016. Supreme Council of Ukraine. Available from: http://zakon5.rada.gov.ua/laws/show/z0183-16 [Accessed June 1, 2019].

Osipian, A. (2017) University autonomy in Ukraine: Higher education corruption and the state. Communist and Post-communist Studies. 50 (3), 233-243.

Ponomarenko, V. (2011) Prediction of dynamics of quantitative indicators of the education system of Ukraine. Mechanisms of regulation of economy. 2, 5-11.

QS World University Rankings 2018. Available from: https://www.topuniversities.com/university-rankings/world-university-rankings/2018 [Accessed June 18, 2019]. 
Sikorskaya, I. (2017) Higher Education Internationalization in Ukraine: Concerns and Hope. International Higher Education. (91), 10-12. Available from: doi.10.6017.2017.91.10126

Stadny, Y. (2017) Ukrainian students abroad: facts and stereotypes. Analytical center CEDOS. Available from: https://cedos.org.ua/uk/osvita/ukrainski-studenty-zakordonom-fakty-ta-stereotypy [Accessed June 19, 2019].

Voloshinov, S., Osadchyi, V. \& Osadcha, K. (2018) Modern trends for higher education in Ukraine. Engineering and Educational Technologies. 6 (4), 38-46. Available from: DOI: 10.30929/2307-9770.2018.06.04.04. 